УДК 130.2:168.522

https://orcid.org/0000-0001-5093-9110

\title{
ФОРМУВАННЯ УРБАНІСТИЧНОГО ПРОСТОРУ СЛОБОЖАНЩИНИ ХVIII ст. (НА ПРИКЛАДІ ТВОРЧОСТІ Г.С. СКОВОРОДИ)
}

О.Ю. Марчак, аспірант кафедри філософії, Харківський національний педагогічний університет імені Г.С. Сковороди

У статті розглядаються особливості формування урбаністичної культури Слобожанщини на протязі ХVIII століття в умовах трансформачії суспільства, змін життєвих настанов, переконань різних страт соиіуму. Доведено, щзо у творчому спадку антропоцентричної філософії Сковороди питоме місие займала урбаністична культура міста, філософ розділяє поняття міста як «града» $i$ «города», виокремлює ідеалізоване рустикальне, щчо опозиціонує «городу». Показана просвітницька роль ідей Сковороди в структуруванні урбаністичного простору Слобідського краю та його бачення основ справедливого суспільства.

Аналіз теми здійснюється в ретроспективі темпорального зрізу історії краю в множині політичних, культурних, соціальних площин та полінаціональних факторів. Розглянуто передумови формування урбаністичного простору Слобожсанщини на прикладі Харкова через особливості заселення, воєнно-демократичний козацький устрій та зовнішні чинники впливу.

Ключові слова: урбаністичний простір, сочіум, антропоцентризм, місто, град, Сковорода, Слобожанщина, справедливе суспільство.

Постановка проблеми. Філософська спадщина Григорія Сковороди вже понад два століття $\epsilon$ предметом вивчення i орієнтиром гуманітарних досліджень в Україні та світі. Поступ нашої країни до європейської спільноти актуалізував питання про історичне підгрунтя цивілізаційних устремлінь українців, а спроби переписати культурні коди народу потребує і екскурсу до витоків - поглядів автора ««первородного сина» східнослов'янської філософії»[1, С. 64], творчість якого сприяла розвитку просвітництва на Слобожанщині.

Важливими філософськими координатами в антропоцентризмі Сковороди $\epsilon$ розмежування міста як «города» $\mathrm{i}$ «града», що в якості переосмисленого концепту сприяло генеруванню в свідомості соціуму важливих моральних наративів та наступним втіленням моделі проєвропейського простору міста (urbanus) на прикладі Харкова. 
Актуальність теми дослідження. Проблема вибору цивілізаційного напрямку України, і не тільки в координатах «Схід - Захід», але й світоглядного підходу та вибору цінностей, що визначатиме найближче майбутнє народу, актуалізує широку проблематику української історії та філософської думки, зокрема, необхідність звернутись до першооснов філософського доробку Сковороди. В цьому контексті погляди філософа на розвиток урбаністичної культури Слобожанщини, та зокрема, як передумови формування міста 3 європейськими рисами несуть в собі значний евристичний потенціал та потребують подальшої розробки.

Стан дослідження теми. На тлі величезної кількості сковородинівських студій - понад 5000 робіт [2, С. 22], та висвітлення найрізноманітніших аспектів творчості українського філософа тема урбаністичної культури Слобожанщини в творчості Сковороди висвітлювались різною мірою в працях Д. Багалія, В. Ерна, О. Сфименко, І. Іваньо, М. Култаєвої, І. Мірчука, М. Поповича, Л. Ушкалова, Д. Чижевського та ін. Закономірності соціокультурного аспекту розвитку центра - периферії розглянуті в роботах О. Роговського, глобальні перспективи урбаністичних утворень - у І. Радіонової, соціально-політичні виміри антропогенної проблематики міста вивчали О. Кузь, Г. Куц, онтоантропологічний простір буття сучасного міста - Т. Філіппова, культурно-антропологічний статус міста - Л. Мачулін та ін. Інтерпретації проекцій просвітництва в європейській філософії досліджує О. Перепелиця. Узагальнююча характеристика відношення Сковороди до сучасних йому процесів у суспільстві - основним ідеям (mainstream) Просвітництва - се куляризації, урбанізації, дається в роботах зарубіжних дослідників Дж. Л. Клайна, Р. Густафсона, Б. Горовіца.

Виклад основних положень. Шанований дослідник філософської спадщини українського любомудра Л. Ушкалов зазначав: «...феномен Сковороди можна як слід збагнути тільки на грунті української традиції» [3, С. 42]. 3 урахуванням завдань нашої роботи зауважимо: щоб сприйняти філософські концепції Г. Сковороди, варто звернути увагу на історичний фон 
та культурно-антропологічні особливості Слобожанщини, де пройшла значна частина життя Григорія Савича, була написана більшість його творів, знаходився життєвий простір спілкування митця.

Сковорода майже не вдається до прямих оцінок проблематики сучасного йому суспільства, врешті, як i iсторичних подій недалекого минулого. Визначаючи призначення та роль людини у світі, митець через призму поетичного сприйняття проблем соціуму здійснює філософську рефлексію онтичного зовнішнього, що є похідним до внутрішнього монологічного Я. Це дозволяє краще визначити себе в багатьох відтінках тлінної буттєвості, як-то війна, насильство, та символ підкорення чужого - вороже місто: «Не хочу за барабаном ити, пленять городов»[3, С. 62]. Вірний своєму кордо-центричному мисленню, філософ бачить вихід людини з мілітаризації життєвого простору, безкінечного протистояння, куди ii втягує держава, політика, соціум у духовному осмисленні сенсу життя окремим індивидом: « Кто сердцем чист и душею / Не нужна тому броня, / Не нужен шлем на шею, / Не нужна ему война» $[3$, С. 70].

Зрушення в духовній цілісності слобожанського соціуму, що перш за все виділяли моральну ницість міста як концентрат влади і багатства, Сковорода добре відчував. Відбувається девальвація традиційних ціннісно-моральних орієнтирів українського суспільства під зовнішнім централізаторським впливом: « При большом наплыве чужеземцев, русских чиновников и служилых людей... вследствие частого и тесного общения полчан (козаків Харківського полку - прим. моя) с ними, нравы их начали портиться. Среди слобожан стали практиковаться доносы друг на друга, благодаря которым возбуждались такие дела, о которых козаки в прежнее время не имели ровно никакого понятия...»[4, С. 114]. Це характеристика петрівських часів. Горезвісне «слово i діло» політичного доносу, особливо в період «біронівщини» імператриці Анни Іванівни, проникло і в звичаї слобідського суспільства. Із збільшенням та ускладненням адміністративного апарату в управлінні життям Слобідського краю в суспільство проникають корупційні 
явища, що мають прояви у всіх верствах соціуму та стають складовою спілкування козацької старшини з вищим чиновництвом імперії [4, С.123]. Правління імператриць Анни Іванівни, Єлизавети Петрівни для Слобожанщини характеризувалось продовженням централізації влади та перетворенням Слобідських полків у зручний людський та матеріальний ресурс для ведення військових компаній, розшарування суспільства завершили укази Катерини II.

Філософ розділяє урбаністичний простір міста поняттями «город» i «град». Антитетика Сковороди «город» - «горный град» набуває того-ж символічного значення, характерного для світогляду філософа, що і в розумінні Біблії як світу зашифрованих символів. Два града - города описані в різних за часом та стилістикою творах, і асиметрично протиставлені одне одному. Поняття міста - (града,города) зустрічаємо в творах Сковороди понад 500 разів. В «Песне 5-й» поетичного циклу «Сад божественых песней» автор вводить образ «горный град»; «свят град» в 20-й Пісні, в цьому-ж контексті «град» вживається у 22-й Пісні. Інші конотації несе в собі «город» як сучасне Сковороді місто, і вживається в поетичних збірках, «Байках Харьковских», філософських діалогах, перекладах.

Ідеальний світ Творця Сковорода виділяє та підкреслює його відмінність від земного світу людей, що є нижчою стратою в онтологічній побудові символічного світоустрою філософа.

«Город» i «горный град» відносяться до двох начал у Сковороди як видиме тварне-недійсне і невидиме вічне-нетлінне: «Кинь весь мір сей прескверный. Он-то вточь есть темный ад. / Пусть летит невеж враг черный. Ты в горный возвысись град» [3, С. 53]. Символ «горный град» покликається до біблійного «Граду небесного» $з$ Одкровення Іоанна Богослова, духовним будівництвом якого потрібно займатись кожній доброчесній людині, і займає у філософа вагоме місце поряд з більш відомими образами серця, сонця, зерня, дзеркала. Автор звертається до трансцендентного біблійного міста як антитези «Миру сему прескверному», маючи на увазі духовне самопізнання 
та вдосконалення, створення свого внутрішнього цілісного «Я» на противагу «миру» як недосконалому суспільству: «И по земле ходя, / Вселися на небесах»[3, С. 53]. Гносеологія Сковороди, на противагу аристотелівській традиції, направлена на внутрішне самопізнання як умову розуміння навколишнього світу та можливість втілення омріяного «граду» через морально-духовну трансформацію індивіда.

«Горный град» Сковороди - це не старогрецьке місто-поліс чи укріплені містечка Слобожанщини. Цей образ перш за все слід розуміти як духовну, екуменічну спільноту людей, об'єднаних ідеєю, а не політичними чи вузькоконфесійними інтересами. Моделлю такого об'єднання, не обмеженого рамками однієї держави, національності чи соціальної групи, за часів Сковороди могла бути православна Церква.

Схоже розуміння «граду Божого» ми зустрічаємо i в Августина Блаженного, який входив до найулюбленіших авторів Сковороди та твори якого мали великий вплив на світогляд українського філософа [3, С. 111]. Августин в своєму творі «Про град Божий» розділяє людське суспільство на дві спільноти - ті, що живуть за законами людей, i ті, хто живе згідно волі Божої. Ці групи об'єднані образами двох різних держав, що різняться за своїми переважаючими потягами, прагненнями. Це суто умовні спільноти, які в емпіричному світі живуть поруч одне із одним, відмінності їх помітні тільки для Творця. Люди завчасно не можуть знати, до якої групи вони належать, істина відкривається тільки на останньому суді. Безпосереднє втілення «граду Божого», із очікуванням, приходом Спасителя, втіленням і стражданням Сина Божого є створення його дому, граду - Церкви [5, ел. ресурс].

В своєму «горному граді» Сковорода, на відміну від Августина Блаженного, бачить суспільство із справедливим соціальним ладом, що можливо вибудувати тут, на Землі, через закони віри та філософію серця, яку може добровільно сприйняти кожна людина у важкому особистому шляху самовдосконалення: «...на Законе ВЕРЫ и СТРАХА БОЖІЯ, яко на главнейшем Пункте» [3, С. 162-163]. Наріжним каменем такого устрою 
український філософ вважає громадянське суспільство, що керується « ручайками Гражданских Законов» [3, С. 162-163].

Такий ідеал морально-етичного суспільства покликається до зразків утопічного соціалізму гуманістів Томаса Мора, Томмазо Кампанелли, однак немає достатніх підстав вважати, що Сковорода міг безпосередньо ознайомитись з їх ідеями, що звісно, не виключає рецепції утопічних соціальних моделей опосередковано, через проникнення в Україну західних філософських концепцій Нового часу на хвилі протестантизму. Л. Ушкалов вважає ідеалом соціального устрою у Сковороди «поєднання Платонової моделі ідеальної республіки з наукою про Церкву як містичне Христове тіло»[3, С.225], що вичерпно характеризує неоплатоністичні погляди філософа, бо вочевидь, на час написання «Начальной двери ко Христїянскому Добронравїю» (1766р.) рабовласницька республіка Платона ще не отримала разючої альтернативи Французької революції в суспільній думці Європи.

Антропоцентризм Сковороди з вірою у людину екстраполюється і на можливість побудови справедливого соціуму. Дослідниця творчості Сковороди О. Єфименко вважала, виходячи з аналізу діалогу «Пря беса с Варсавой», що філософ відносив себе до «вибраних»- Моісея, патріархів і пророків, яким відкривається Біблія, та ставив завдання будівництва нового Ізраїлю - справедливого суспільства: «Сковорода ставил создание этого нового Израиля путем личного воздействия пропаганды, как можно выразиться на современном языке. Впереди, и в недалеком будущем, ему, полному страсти энтузиасту, мерещилось «второе время», «царство Божье», «жизнь вечная», когда огнем разумения будет пожрано все мертвенное, тленное, стихийное человеческой природы, и земля сделается «землей живых, страной и царством любви, горним Иерусалимом...без вражды и раздора, где все общее, где общество будет в любви, любовь в Боге, Бог в обществе...» [6, С. 440 - 441]. Вочевидь, революційні настрої кінця ХІХ ст., коли була написана ця робота, впливали на оцінку ролі Сковороди в 
екзистенційній спроможності задумів з реформування, зміни суспільства на нове царство Ізраїлеве; авторське бачення поглядів українського філософа вирізняється від його традиційного сприйняття дослідниками XIX ст. як оригінального філософа, але не бунтаря.

Століття $з$ дня смерті видатного мислителя, та особливо копітка праця Д. Багалія, стали поштовхом до фактичного повернення філософського насліддя Сковороди у науковий обіг. А через відсутність звичного для сприйняття читаючим загалом викладу поглядів Сковороди у вигляді стрункої філософської системи дослідники творчої спадщини філософа трактували його погляди у відповідності із своїми світоглядними позиціями, що має місце і в сучасному сковородинознавстві. Тут можна погодитись із тезою, що «філософські універсалії є складниками певних ідеологічних побудов» [7, С. 11].

Однією із сторін такого інваріантного підходу $\epsilon$ оцінка позиції Сковороди щодо ролі церкви, християнства та його власної релігійності. Критичні зауваження філософа щодо дослівного прочитання біблійних сюжетів чи порівняння Христа 3 Епікуром на підставі кількох цитат використовувались марксистськими та деякими радянськими дослідниками для трактування поглядів Сковороди як атеїста, а його філософії як матеріалістичної. Сьогодні важно знайти прихильників цієї точки зору; дискурсивний потенціал скоріше несе в собі оцінка відношення Сковороди до секуляризаційних процесів в українському, та зокрема, слобожанському суспільстві вісімнадцятого століття. Оскільки неоднозначним є розуміння самого терміну saeculum, а тема оцінки філософсько-релігійного світобачення українського філософа виходить за рамки нашої роботи, позначимо лише внутрішній зв'язок секуляризації та процесів урбанізації в ранньомодерній Україні, на що звернув увагу закордонний дослідник творчості філософа Джордж Л. Клайн. Американський вчений вважає, що Сковорода «... стояв проти того, що стало називатися «проект Просвітництва», протиставляючи в цілому основним ідеям (mainstream) вісімнадцятого століття свої думки та переконання. Вісімнадцяте століття 
було відзначено секуляризацією, і він противився цьому. Воно також ознаменувалося урбанізацією - ... і він виступав проти цього... точніше, він виступав не проти міста як такого... але певні речі, які представляли місто: 3 одного боку, передові науки та технології; 3 іншого боку, гонитва за вишуканим комфортом, розкішшю та задоволенням» [8, С. 64]. Різноплановість світсько-церковних, а в духовному - сакрально-профаних тенденцій в західному світі і сучасній Сковороді Україні відкриває поле для дискурсу щодо можливостей екстраполяції західної моделі секуляризації та багатопланової сфери структурування нового урбаністичного простору на український грунт.

Однією із підвалин фундаменту для нового суспільства Сковорода вважає Премудрість (Софію). Філософ деталізує характеристику Премудрості як першооснови, що дається Творцем та до якої прагне як окремий індивід, так і суспільство, а за мірою її осягнення людина відчуває «блаженство, или удовольствїе», люди стають спроможними «к Содружеству и к помянутим Сожительствам годными» [3, С. 215].

Але на відміну від західних утопістів Ренесансу, що створювали свої ідеальні світи саме в містах, Сковорода вважає сучасне йому урбаністичне середовище концентрованим проявом негативних рис людської природи та осередком зла: «Города славны, высоки, на море печалей пхнут / Ворота красны, широки, в неволю горькую ведут» [3, С.62]. Філософ негативно сприймає зміни у суспільстві, пов'язані із переважанням грошовоматеріальних відносин та девальвацією моральних принципів, орієнтацією на сумнівні для нього цінності 3 первнем матеріального над духовним: «Пропадайте думы трудны! / Города премноголюдны! / А я с хлеба куском умру на месте таком» [3, С. 63].

Сковорода асоціює свої «думы трудны» саме з багатолюдними містами, що водночас, даючи освіту, спілкування, розвиток, нові можливості, все ж виштовхували митця 3 суворо стратифікованого соціуму із застигаючою державно-теологічною матрицею в суспільній свідомості. Філософ постійно 
підкреслює діалектичну протилежність поза-урбаністичного простору, де внутрішня свобода сільського привільного буття в образі автобіографічного пастуха 3 сопілкою $\epsilon$ опозицією місту, яке із втіленням військовоадміністративних та культурних реформ Катерини II швидко ставало відокремленим чужим у свідомості козацько-селянської більшості.

Слобідський край до середини вісімнадцятого століття - це рідко заселені простори, 3 полковим козацьким устроєм та населенням, що переважно займалось сільським господарством, ремеслами та невеликими переробними промислами в полкових і сотенних містечках.

Відбувається поступове економічне, адміністративне, політичне та військове підпорядкування Слобожанщини інтересам Російської імперії, посилюється адміністративна роль російського чиновництва, козацькі полковники та старшина все більш обмежуються у своїх повноваженнях [4, C. 111-112].

На Слобідську Україну з переважаючими «малоросами» (українці) та меншою часткою великоросів (росіян) в національному відношенні [9, С.14], за ініціативою царської влади переселяються інші народності - валахи [9, С. 98, 113], серби [9, С. 124], Харківський полк утримував полонених шведів [9, С. 104]; торгівля, переселенці, постої військ, роздача земель російському дворянству із їх іноземними управителями створювали на цій території особливий поліетнічний конгломерат. Само-ідентифікація українців як широкий антропо-культурний та національний феномен, що «дає змогу виокремити себе 3 поміж інших, сформулювати аргументи на користь власної самоповаги» [10, С. 124] в результаті цілеспрямованих зусиль центральної влади розмивається, аж до прикладів історичної амнезії на такі імена, як гетьман Мазепа[9, С. 20]. 3 указів Петра I починається заборона книгодруку українською мовою, вилучення текстів церковних книг українською, підпорядкування українських монастирських друкарень московському синоду[11, С. 22]. Водночас взаємовпливи культур українського та інших народів створювали на Слобожанщині сприятливий 
клімат релігійної, культурної, етнічної толерантності.

У другій половині вісімнадцятого століття обмежується та забороняється використання української мови в Києво-Могилянській академії, видання українського букваря, із ліквідацією в 1764 р. козацького устрою на Слобожанщині закриваються і всі українські школи при полкових канцеляріях. 31804 року викладання українською припиняється повністю, як наступає і параліч видавничої справи. Уряд Павла I забороняє приватні друкарні та ввіз іноземної літератури.

В той-же час Академія в Києві, заснована на принципах гуманізму та просвітництва, що довгий час була єдиним вищим навчальним закладом в Східній Європі та всього православного світу, стає колискою та кадровим джерелом побудови освіти, науки, церковної реформи в Російській імперії. У Москві працювали просвітники Дмитро Ростовський (Тупало), Стефан Яворський, Феофан Прокопович. Український вплив проявляється у всіх сферах життя: «Українці принесли з собою всю свою велику культуру, і вплив їхній одбився на Москві на всьому житті... і навіть на самій московській мові».[12, С.75-76]. Викладачі та випускники Київської академії у XVIII ст. стали засновниками шкіл, семінарій у багатьох містах Росії і Білорусії.

Розвиток Слобожанського суспільства з початку вісімнадцятого століття міняє свій вектор із військово-демократичного козацького устрою на централізацію бюрократично-адміністративного характеру як частини Російської імперії. Даровані козакам свободи систематично викорінюються, на протязі століття Слобідський край цілеспрямовано перетворюється на рядову губернію, що закріплюється статусом Харкова як губернського міста з 1765 року із утворенням Слобідсько-української губернії [13, С. 156.].

Зростання торгівлі, прокладення через Харків торгових шляхів на Лівобережну Україну, південь сприяли господарському розвитку, створенню спільного соціо- та етнокультурного простору з елементами європейського впливу [13, С. 164.], місто через своє вигідне розташування поступово стає 
економічним, торговим центром.

На такому антропо-історичному фоні Харків XVIII ст. вибудовує унікальну освітню систему та в цілому соціокультурне середовище через збіг кількох, зовні мало пов'язаних факторів, що створили синергетику своєрідного культурного простору, серед яких можна виділити наступні:

- відносна віддаленість від російських столиць певною мірою стримувала швидке адміністративно-політичне та культурно-економічне підпорядкування Слобожанщини Російській імперії, зменшувала політичний тиск на громадську спільноту міста;

- прикордонний статус, майже століття загрози татарських набігів, полковий козацький устрій території військо-демократичного характеру та безперервні військові компанії XVIII ст. формували у Слобідському краї відмінну від метрополії ментальність, що була настояна на свободі, яку захищали із зброєю в руках;

- скасований на Слобожанщині полковий устрій в 1764 році все-ж зберігав традиції демократизму відносин між станами, та 3 врахуванням політики центральної влади давав соціально-економічні можливості, як-то отримання особистого дворянства чи освіти дітям 3 незаможних сімей у Харківському колегіумі;

- розміщення Слобожанщини на перетину важливих торгових шляхів створювало додатковий стимул економічному та культурному розвитку, формувало етнічну терпимість в полінаціональній спільноті;

- загальна імперська політика на обмеження національної освіти, науки, культури в традиційному центрі - Києві та містах Лівобережної України, в Харкові як адміністративному центрі Слобожанщини отримала дещо контроверсійний напрямок на утворення нової освітньої системи. Культурнопросвітницьким традиціям та прагненню усіх верств до освіти відповідали зусилля впливових попечителів - духовенства, генерал-губернаторів краю, що формувались під впливом небайдужої еліти, діячів культури;

- важливе місце посідає просвітницько-філософська роль 
Г.С. Сковороди, спрямування думок сучасників у демократичне поле європейської традиції. Послідовники та однодумці - «сковородинівці» через 9 років після смерті філософа відкрили Харківський університет, продовжили ідеї Сковороди в розвитку української самосвідомості. М.Д. Култаєва вважає, що: «...значну роль відіграє позбавлена ідеологічного примусу інтелектуальна традиція, започаткована Сковородою. Він значно посилив західноєвропейську складову в українській культурі 3 акцентуванням модерних семантик свободи, щоправда, в стилістиці українського літературного бароко». [14, С. 172]

- відкриття університету створило новий центр освіти та культури, що поряд 3 відкриттям Московського університету змінило пріоритет КиєвоМогилянській академії як єдиної вищої школи, яка при систематичній відсутності підтримки та рецепції кадрів у російські столиці врешті була закрита у 1817 р. Утворення нового наукового та освітнього центру на Слобожанщині супроводжувалось залученням європейських вчених, зокрема i представників німецької філософської школи, що об’єктивно надавало Харкову рис європейського міста;

- новий за терміном створення, заселення край із принесеними, але ще не вкоріненими національними традиціями українського, російського та інших народів сприяв виникненню феномену, що пізніше та на іншому континенті дістав назву «американського котла», де виплавлялась культура із своїми особливими рисами.

Парадоксальний розрив між, 3 одного боку, загальноприйнятим суспільним ідеалом матеріального достатку як маркером успіху і щасливого життя, і з іншого, повна зневага до матеріального у Сковороди у поєднанні із духовною свободою, що іноді приймала форми гострого конфлікту 3 церковно-державними структурами, викликала у сучасників Григорія Савича різні почуття, крім байдужості. М. Попович розглядає сковородинівський стиль життя і філософствування як «лімінальну дивність» та відмову від будь-яких соціальних позицій, щоб лишитись самим собою [15, С. 11-14]. 
Погоджуючись 3 цією думкою, усе ж закцентуємо, що Сковорода, ведучи таке скромне життя за переконанням, а не з необхідності, зайняв те сакральне місце духовного провідника та морального авторитета нації, що тільки самостверджувалась, хоч ніколи не шукав сліпих послідовників та не формував щось на кшталт секти чи масонської ложі. Слово Сковороди - це пробудження вільної думки у своїх учнів, це рівноправний, але критичний діалог у колі добрих знайомих. Про це нам свідчать історії відносин Сковороди із своїми учнями. Крім М. Ковалинського, завдяки якому ми маємо найважливіше джерело біографії Григорія Савича, чи листів Василя Томари, який на вершині успішної кар'єри дипломата, сенатора з безмежною повагою зізнавався Сковороді, що потребує, як і раніше, доброго слова i поради вчителя та сподівається ще на зустріч [16, С.482], були сотні невідомих нам, таких же вдячних учнів, яким прищепив Сковорода свій дух внутрішньої свободи. I саме ця незалежність із простими ясними ідеями біблійної справедливості, без відкритої протестантської ревізії Святого письма та соціальних гасел утопічного соціалізму, що з Просвітницьких утопій XVI-XVII ст. переростали в Свропі в кровопролиття під егалітарними гаслами загальної рівності Французської революції, викликала розуміння і прийняття Сковороди як філософа та особистості серед широких верств українського суспільства.

\section{Список використаних джерел}

1. Scherer S. The Narcissus: Skovoroda's "First-Born Son”// Journal of Ukrainian Studies. - 1997. - Vol. 22. Nos. 1-2. Р.52 - Електрон.версія URL 64http://diasporiana.org.ua/wp-content/uploads/books/13741/file.pdf (дата звернення 26.01.2019).

2. Ушкалов Л. На риштованнях історії української літератури - дещо про рецепцію нашої класики / Ушкалов Л. // Університетські діалоги, 2007, №3. С.22-54.

Електрон.версія URL https://epdf.tips/-82e9a80c36fe7de0c309f660cdba5efe4708.html (дата звернення 12.03.2019)

3. Сковорода Григорій. Повна академічна збірка творів / За редакцією проф. Леоніда Ушкалова. - Харків Едмонтон-Торонто: Майдан; Видавництво Канадського Інституту Українських Студій, 2011. - 1400 с. Електрон.версія URL https://kharkiv-nspu.org.ua/wpcontent/uploads/2014/05/Skovoroda_povn_z_portretom_opt.pdf. (дата звернення 4.12.2018).

4. История Харьковского козачьего полка (1651-1765) / По архивным материалам составил Е.Альбовский. Тип.Губенр.Правл. - Харьков, 1895. - 231 с. Електрон.

версія URL http://otkudarodom.ua/sites/default/files/pdfs/1895 albovskiy harkovskiy polk.pdf (дата звернення 02.03.2019).

5. Августин Аврелий блаженный. О граде Божьем // Азбука веры. Православная библиотека: електронн. версия библ. 2019. URL https://azbyka.ru/otechnik/Avrelij_Avgustin/o-grade-bozhem/ (дата звернення 
8.02.2019).

6. Ефименко А.Я. Личность Г.С. Сковороды как мислителя / Ефименко А.Я. // Вопросы философии и психологи. [Журнал / Основ. проф. Н.Я. Гротом и А.А. Абриковосовым; под ред.проф. Н.Я. Грота и Л.М. Лопатина]. - Москва, Типо-литография Высоч. Утвержд. Т-ва И.Н.Кушнеров и К ${ }^{\circ}-1894 .-$ Год V. Книга 25(5). Ноябрь 1894г. - С. 419 - 445.// Спілка української молоді. Статті. Українська філософія. [Харків]. - Режим доступу : http://cym.org.ua/ukrayinska-filosofiya/ (дата звернення 28.02.2019).

7. Левченко Н. Сковородіана Леоніда Ушкалова / Левченко Н. // Ліствиця Якова: збірник статей на пошану професора Леоніда Ушкалова з нагоди його шістдесятиліття. [Упорядник: Н. Левченко; наук. ред. Р. Мельників]. - Харків: Майдан, 2016. - 490 с.

8. George L. Kline. Skovoroda: In but Not of the Eighteenth Century. A Commentary // Journal of Ukrainian Studies: електрон. версія журн.: Summer-Winter 1997. . - Vol. 22. - Nos. 1-2. Р.117 - 122. Режим доступу: http://diasporiana.org.ua/wp-content/uploads/books/13741/file.pdf (дата звернення 26.01.2019).

9. Статистическое описание Харьковской губернии // [ б.а., вид-ва та дати вид., не раніше 1862 р. Шифр зберіг.61892 ЦНБ ХНУ ім. Каразіна] - 64 с.

11. Розпутенко I. Забуття українців / Розпутенко І. - Київ: «К.І.С.», 2008. - 180 с.

Електрон.версія. - Режим доступу : books.google.com.ua/books (дата звернення 07.03.2019)

12. Огієнко І. Українська культура / Огієнко І. // [Репринт.відтворен.вид.1918 р.] - Київ: «Абрис», 1991. - 272 с.

13. Багалій Д.І. Український мандрований філософ - Григорій Савич Сковорода. Його життя, філософія і значіння / Багалій Д.І. - Харків: Держ. вид.України, 1923. - 144 с.

14. Култаєва М.Д. Під знаком Григорія Сковороди: філософсько-педагогічні розвідки / Култаєва М.Д.// Філософія освіти. 2017, № 2. - С.169-193

15. Попович М. Григорій Сковорода: філософія свободи / Попович М. - К.: Майстерня Білецьких, 2008.- 256 с.

16. Сковорода Григорій. Повне зібрання творів // Твори в двох томах, т.2. Київ: Наукова думка, 1973. - 576 с.

\section{References}

1. Scherer S. The Narcissus: Skovoroda's "First-Born Son" // Journal of Ukrainian Studies. - 1997. - Vol. 22. Nos. 1-2. P.52 - Електрон.версія URL 64http://diasporiana.org.ua/wp-content/uploads/books/ 13741/file.pdf (дата звернення 26.01.2019).

2. Ushkalov L. Na ryshtovannjah istorii' ukrai'ns'koi' literatury - deshho pro recepciju nashoi' klasyky / Ushkalov L. // Universytets'ki dialogy, 2007, №3. S.22-54

Elektron.versija URL https://epdf.tips/-82e9a80c36fe7de0c309f660cdba5efe4708.html (data zvernennja 12.03.2019).

3. Skovoroda Grygorij. Povna akademichna zbirka tvoriv / Za redakcijeju prof. Leonida Ushkalova. - HarkivEdmonton-Toronto: Majdan; Vydavnyctvo Kanads'kogo Instytutu Ukrai'ns'kyh Studij, 2011. - 1400 s. Elektron.versija URL https://kharkiv-nspu.org.ua/wpcontent/uploads/2014/05/Skovoroda_povn_z portretom opt.pdf. (data zvernennja 4.12.2018).

4. Istorija Har'kovskogo kozach'ego polka (1651-1765) / Po arhivnym materialam sostavil E.Al'bovskij. Tip.Gubenr.Pravl. - Har'kov, 1895. - 231 s. Elektron.Versija URL http://otkudarodom.ua/sites/default/files/pdfs/1895_albovskiy_harkovskiy_polk.pdf (data zvernennja 02.03.2019).

5. Avgustin Avrelij blazhennyj. O grade Bozh'em // Azbuka very. Pravoslavnaja biblioteka: elektronn. versija bibl. 2019. URL https://azbyka.ru/otechnik/Avrelij_Avgustin/o-grade-bozhem/ (data zvernennja 8.02.2019).

6. Efimenko A.Ja. Lichnost' G.S.Skovorody kak mislitelja / Efimenko A.Ja. // Voprosy filosofii i psihologi. [Zhurnal / Osnov. prof. N. Ja. Grotom i A.A.Abrikovosovym; pod red.prof. N.Ja.Grota i L.M.Lopatina]. - Moskva, Tipo-litografija Vysoch. Utverzhd. T-va I.N.Kushnerov i Ko -1894. - God V. Kniga 25(5). Nojabr' 1894g. - S. 419 - 445.// Spilka ukrai'ns'koi' molodi. Statti. Ukrai'ns'ka filosofija. [Harkiv]. - Rezhym dostupu http://cym.org.ua/ukrayinska-filosofiya/ :(data zvernennja 28.02.2019).

7. Levchenko N. Skovorodiana Leonida Ushkalova / Levchenko N. // Listvycja Jakova: zbirnyk statej na poshanu profesora Leonida Ushkalova z nagody jogo shistdesjatylittja. [ Uporjadnyk: N. Levchenko; nauk. red. R. Mel'nykiv]. - Harkiv: Majdan, 2016. - 490 s.

8. George L. Kline. Skovoroda: In but Not of the Eighteenth Century. A Commentary // Journal of Ukrainian Studies: електрон. версія журн.: Summer-Winter 1997. . - Vol. 22. - Nos. 1-2. P.117 - 122. Режим доступу: http://diasporiana.org.ua/wp-content/uploads/books/13741/file.pdf (дата звернення 26.01.2019).

9. Statisticheskoe opisanie Har'kovskoj gubernii // [ b.a., vid-va ta dati vid., ne ranishe 1862 r. Shifr zberig.61892 CNB HNU im.Karazina] - $64 \mathrm{~s}$.

10. Musijezdov O. Identyfikacija Harkova: dosvid konstrujuvannja obrazu mista / Oleksij Musijezdov // Shid - Zahid. Istoryko-kul'turologichnyj zbirnyk. Problemy istorychnoi' urbanistyky: za red. 
V. Kravchenka, G. Grinchenko. - Harkiv: TOV «NTMT», 2011. - Vyp. 15. - S.217-234 Elektron.versija. Rezhym dostupu : https://www.academia.edu/6997326/ (data zvernennja 06.04.2019).

11. Rozputenko I. Zabuttja ukrai'nciv / Rozputenko I. - Kyi'v: «K.I.S.», 2008. - 180 s.

Elektron.versija. - Rezhym dostupu : books.google.com.ua/books (data zvernennja 07.03.2019)

12. Ogijenko I. Ukrai'ns'ka kul'tura / Ogijenko I. // [Reprynt.vidtvoren.vyd.1918 r.] - Kyi'v: «Abrys», 1991. - 272 s. Elektron.versija. URL http://chtyvo.org.ua/authors/Ohiyenko Ivan/Ukrainska kultura/ (data zvernennja 07.03.2019).

13. Bagalij D.I. Kratkij istoricheskij ocherk o torgovle (preimushhestvenno jarmarochnoj) v Har'kovskom krae v HVII i HVIII vv./ Bagalij D.I. // Har'kovskij vestnik, 1888g. c.148-172. Elektron.versija версія

URL https://books.google.com.ua/books?id=yWvUAAAAMAAJ

\&printsec $=$ frontcover $\& \mathrm{hl}=\mathrm{ru} \# \mathrm{v}=$ onepage $\& \mathrm{q} \& \mathrm{f}=$ true $($ data zvernennja 25.03.2019).

14. Kultaeva M.D. Pid znakom Grygorija Skovorody: filosofs'ko-pedagogichni rozvidky / Kultajeva M.D.// Filosofija osvity. 2017, № 2. - S.169-193

15. Popovych M. Grygorij Skovoroda: filosofija svobody / Popovych M. - K.: Majsternja Bilec'kyh, 2008.- $256 \mathrm{~s}$.

16. Skovoroda Grygorij. Povne zibrannja tvoriv // Tvory v dvoh tomah, t.2. Kyi'v: Naukova dumka, 1973. $-576 \mathrm{~s}$.

\section{ФОРМИРОВАНИЕ УРБАНИСТИЧЕСКОГО ПРОСТРАНСТВА СЛОБОЖАНЩИНЫ ХVIII В. (НА ПРИМЕРЕ ТВОРЧЕСТВА СКОВОРОДЫ)}

\section{А. Марчак}

В статье рассматриваются особенности формирования урбанистической культуры Слобожанщины на протяжении XVIII века в условиях трансформации общества, изменения жизненных установок, убеждений различных слоев социума. Доказано, что в творческом наследии антропоцентрической философии Сковороды важное место занимала урбанистическая культура города, философ разделяет понятия города как «града» и «города», выделяет отдельные понятия «деревни» и «города». Показана просветительская роль идей Сковороды в структурировании урбанистического пространства Слободского края и его видение основ справедливого общества. Анализ темы осуществляется в ретроспективе темпорального среза истории края во многообразии политических, культурных, социальных плоскостей и полинациональных факторов. Рассмотрены предпосылки формирования урбанистического пространства Слобожанщины на примере Харькова через особенности заселения, военнодемократический казацкий строй и внешние факторы влияния.

Ключевые слова: урбанистическое пространство, социум, антропоцентризм, город, град, Сковорода, Слобожанщина, справедливое общество.

\section{FORMATION OF THE URBAN SPACE OF SLOBOZHANSHCHYNA OF THE XVIII CENTURY (ON THE EXAMPLE OF G.S. SKOVORODA'S CREATIVITY)}

\section{Alexander Marchak}

The article considers the peculiarities of the formation of the urban culture of Slobozhanshchina during the eighteenth century in the conditions of the transformation of society, changes in the way of life guidance, and beliefs of various stratums of society.

It is proved that the theme of the city occupies a special place in the creative heritage of anthropocentric philosophy of Skovoroda. The philosopher shares the notion of the city as"ghrad"(staroslav.) and "city," which distinguishes the idealized rustic that opposes the "city." The educational role of Skovoroda ideas in structuring the urban space of the Slobodsky Krai in the democratic field of European tradition is shown. The Ukrainian philosopher, along with Augustine and the Blessed Utopians of the Renaissance, described his vision of the foundations of a just society as his"ghrad"(staroslav.) . Determining the role of man in the world Frying pan carries out through the philosophical reflection of the ontological external through the internal monologue of the subject. Exit from the ontological situation of violence, war, confrontation of 
the philosopher through the collective image of the city sees in the moral integrity of man.

The analysis of the topic is carried out in the retrospect of the temporal cut of the history of the region in a plurality of political, cultural, social and multinational factors. The policy of central government in Sloboda Ukraine during the XVIII century. from the decrees of Peter I to the transformations of Catherine II, is schematically traced in parallel with the philosophical thought of the Ukrainian thinker. The emphasis is on the peculiarities of the formation of the ethnic diversity of the region.

The transformation of Ukrainian society by the example of Slobozhanshchyna under the influence of the centralization policy of the Russian Empire has no direct reflection in the philosophical work of Skovoroda. Being manifestations of society - politics, economics, state reforms - through the prism of anthropo-philosophical reflection appear in the Ukrainian philosopher the concept of a redefined "inner man" with a complete Christian morality.

The preconditions of formation of the urban space of Slobozhanshchyna on the example of Kharkiv due to the features of settlement, the military-democratic Cossack system and external factors of influence are considered. A set of factors of the formation of the cultural center of the Sloboda region, which created the synergy of the creation of a pro-European city

Key words: urban space, socium, anthropocentrism, city,"ghrad"(staroslav.), Skovoroda, Slobozhanschina, fair society. 